\title{
Strategic Silence in Competitions Between Great Powers
}

\author{
William F. Harlow
}

A

state does not become a great power by being seen as great. Rather, it becomes a great power by consistently advancing its interests. Unfortunately, in the United States (as in many other places) leaders are not often rewarded for actually advancing long-term interests in competitions with other powers. Rather, those leaders are rewarded for the popular perception of what they have achieved over a much shorter time period. Additionally, competitions between aspiring powers are not generally settled so neatly as sporting contests with a clear winner. The participants in great power competitions don't always know when the contest has ended, and the parameters for what constitutes a win can be fuzzy. Even when a win is obvious, it often comes well after a typical term of political office has expired. During the height of the Cold War, for example, the United States and the Soviet Union made a series of competing claims about who was "winning" the struggle for global influence. These claims included numbers of astronauts launched, or the number of countries to which troops were deployed, or the size of economies-truly, the claims included anything which made one side or the other appear to be "ahead." The problem is that, unlike a sports match with a well-defined score, these claims didn't actually define who was winning. These claims defined who should be seen as winning, which isn't the same thing. Rather, it would be something like determining the winner of the match based on whose fans were cheering the loudest.

For great powers, and those states which aspire to be great powers, the important factor is defining their own interests and finding a way to advance those interests. While that might very well involve a public influence campaign, it would not always need to. Indeed, sometimes the way for a great power to win any given competition is to simply let those interests advance without any direct influence. In this essay, I make two arguments. First, I argue that great powers should principally focus on defining and advancing their interests rather than been seen as the winner of some sort of global competition. Second, I argue that being seen to win is sometimes detrimental to actually winning. In order to advance these arguments, I will first define the term "strategic silence," or the notion that policy actors need not always publicly advocate for their goals. Having defined that term, I provide a framework for understanding it and will review some of the cases when states have attempted to use this strategy to advance their interests. I 
conclude with a case study exploring at greater depth the time President George H.W. Bush successfully advanced American interests at the end of the Cold War by practicing strategic silence on the collapse of the Soviet Union. To be clear, my purpose in this paper is not to say that great powers should not publicly advocate for their best interests nor that presidents shouldn't speak. Of course they should. Rather, the focus of great powers should be the actual advancement of those interests rather than the public advocacy for them.

\section{A Framework for Understanding Silence}

number of studies have at-
tempted to define strategic si-
lence, and this study construes the concept narrowly as the intentional choice of an empowered actor who might have spoken and instead decided to remain silent in order to advance a policy goal. A president of the United States is certainly an empowered actor who could speak and receive significant attention for his words; silence in the sense discussed here would also require that the failure to speak arose from having made an intentional choice in hopes of advancing some policy issue. In other words, President Biden's failure to announce what he had for lunch is not a strategic silence, but declining to discuss his preferred outcomes for a meeting with Russia's President Putin might be. This is similar to the definition of silence provided by Barry Brummett (1980, p. 289), who defined "political strategic silence" as "the refusal of a public figure to communicate verbally when that refusal (1) violates expectations, (2) draws public attributions of fairly predictable meanings, and (3) seems intentional and directed at an audience." Brummett (p. 290) also argued that silence was "relative to what might be said," and a leader saying less than might otherwise have been said would still be employing silence as a rhetorical tool. Brummett's definition would thus allow, for example, brief statements and other comments. In the example of an American president, it would also allow for having a statement made by a cabinet officer, press secretary, or some other officials. While any of those officers are important, their words carry less weight than a direct statement from the sitting president.

One of the limits of a strategic silence, at least in the U.S., is that "the public has a powerful expectation the president will speak in response to crises, particularly in foreign policy." (Harlow, 2018) That begs the question of what constitutes a foreign policy crisis. Denise Bostdorff (1994, p. 205) spoke to this when she noted that, "Contemporary commanders-in-chief promote foreign crises by explicitly advancing a claim of crisis or implicitly treating a circumstance as a crisis in their public discourse." In other words, there is a public demand for the U.S. president to speak, but that demand often comes from something which the president himself has defined as important. Unfortunately, presidents frequently miscalculate what their response to a foreign policy situation should be. As Kiewe (1994, p. xxxiii) explains: 
To a degree, most modern presidents have miscalculated their crisis construction-especially their initial response-often in favor of immediate rewards. The presidency as an institution, with some noted exceptions, has been slow to comprehend the longrange impact of its crisis rhetoric. Indeed, crisis rhetoric has often been executed with immediate image considerations and as a political tool for quick policy goals. The modern presidency, with some exception, does not seem to appreciate the limits of its own crisis rhetoric.

The U.S. public demands that the president speak in response to moments of foreign policy crisis. While there are exceptions, those crises are often perceived as such because the president has talked about them in the first place. When presidents do talk about a foreign policy crisis, they have not historically been very good at knowing what to say. For every time that President Roosevelt asked Congress to declare that a state of war existed between the United States and the Empire of Japan, history is littered with dozens of examples of a president giving a speech which is not particularly helpful. So what studies have been done exploring the concept of intentional strategic silence?

Before Brummett (cited earlier) wrote his article, Johannesen (1974) issued a "plea for communication research" into the functions of silence, and few have answered. While I previously studied the strategic silence of the
Saudi coalition in response to the embargo against Qatar (Harlow, 2018b), most of the studies which do exist on strategic silence have examined either a response from a U.S. actor or a response from the United States itself. Gunderson (1961) studied President Lincoln's silence between his first election and inauguration, concluding that Lincoln used silence well since he did not yet have the powers of the presidency. That meant he would signal intentions to an opponent without having the power to act on his words . Edwin Black (1994) also studied silence by President Lincoln in his Gettysburg address. This helped illustrate Brummett's concept that silence is relative to what might be said rather than absolute, because President Lincoln certainly did speak on that occasion. However, his speech was less than one-third the length of the opening prayer for the occasion. Lincoln acknowledged that his task was to honor the sacrifice of the fallen soldier, and Black praised Lincoln for limiting his remarks.

Similar to the studies of Lincoln, Kurt Ritter (1994) argued that President Lyndon Johnson did well to stay mostly silent in the immediate aftermath of President Kennedy's assassination. With the nation in mourning, it would have been awkward for President Johnson to have given speeches advancing a specific policy agenda. Ritter noted that "Johnson said as little as possible in public," and this allowed him to quietly consolidate his power in the White House while the press portrayed him as a strong leader. President Johnson would, of course, eventually need to 
speak to assert the powers of the presidency, but he only gave a major address after the burial of President Kennedy.

Of the limited number of studies on intentional strategic silence, several have focused on U.S. foreign policy. Medhurst (1988) believed President Truman wrong for his silence on Soviet expansion immediately after World War II. Truman was "given multiple opportunities to explain and justify his foreign policy," and instead failed to "define and regulate the rhetorical environment." (Medhurst, 1988, p. 52) Medhurst's argument reminds us that there are times when the interests of a great power, in this case the United States, are indeed advanced by clear public advocacy. Writing in Foreign Policy, John Dugard (1982) reached a similar conclusion. Dugard evaluated President Reagan's quiet diplomacy in response to apartheid in South Africa. This was, in effect, an intentional strategic silence. Dugard said that some Reagan administration officials believed that the Carter administration's denunciation of apartheid led to the overwhelming victory by the Nationalist Party in South Africa's 1977 elections. Dugard (p. 48) disagreed and believed Reagan's silence to be strategically ineffective: "The United States should focus attention on the growing evidence of renewed discrimination and repression in South Africa. Where quiet diplomacy has failed to produce reform, silence may not be wise." Examining a later period in U.S.- South Africa diplomacy, I (Harlow, 2011a) argued that President George H.W. Bush did well to not pressure President de Klerk concerning apartheid. President Bush believed that the strategic interests of the United States were with a democratic South Africa, and intelligence reporting told Bush that de Klerk was preparing to release Mandela from prison and hold elections. Bush took extraordinarily heavy criticism for his failure to condemn South African racism, but he also knew that doing so would cause de Klerk to have to show in public that he was standing up to a great power. That would have seriously risked derailing the democratic project in South Africa, which would have directly impacted the expressed interests of the United States.

There are several other essays on the rhetorical choices the Presidents Bush made to remain silent in order to advance American interests. The younger President Bush made a strategically effective choice to not challenge China as loudly as he might have concerning manipulation of their currency (Harlow, 2010), and the elder President Bush made a strategically mixed choice in not challenging China concerning the 1989 massacre in Tiananmen Square (Harlow, 2020). The younger President Bush should probably have been more aggressive in response to the poorly conducted elections in $\mathrm{Ni}$ geria in 2007 (Harlow, 2011b). The elder President Bush did extraordinarily important work when he resisted public pressure to celebrate the end of the Cold War on the collapse of the Berlin Wall (Harlow, 2006). Archival documents in the George Bush Presidential Library (hereafter, GBPL) indicate that doing so would have risked angering a still-extant Soviet Union which had previously lashed out in response to similar situ- 
ations. These studies all seem to point in the same direction: If rhetorical intervention by the United States will actually help advance policy goals, then we should be all means have the president and other officials speak loudly and forcefully. The important thing, though, isn't the speaking - it is the advancement of interests. Sometimes the interests of a great power are better served by not speaking-or by speaking more quietly than they might-in order to allow events to proceed in an already favorable direction. In the next section of this essay, I will examine the choices President George H.W. Bush made at the end of the Cold War to advance the interests of the United States. ${ }^{1}$

\section{George H.W. Bush and the Fall of the Soviet Union}

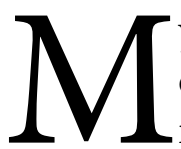
$y$ purpose here isn't to fully explain the actions of President Bush at the end of the Cold War. Instead, my purpose is to explain the choice by President Bush to maintain a strategic silence and show how that choice advanced U.S. policy goals. Specifically, here I want to look at what President Bush didn't say on the collapse of the Soviet Union. President Bush took significant public criticism for failing to celebrate the downfall of the USSR. He wasn't seen as great, and his public reputation took a significant hit. Ultimately, he lost his re-election battle the following year (although there were many reasons for that). Rather than being seen as a great leader at the head of a great state, he was concerned with advancing the interests of the United States. As a result, the United States managed a particularly tricky spot at the end of the Cold War and became the unchallenged global power in the years that followed. I have covered President Bush's response to the collapse of the USSR at different depth and with a different focus in a different outlet (Harlow, 2014), and since that time significant new records have been released which detail the conversations between Bush, Gorbachev, and Yeltsin.

On or about August 19, 1991, leaders in Mikhail Gorbachev's own government plotted a coup d'etat against him and arrested him at his vacation home. Coup leaders sent tanks into Moscow as a show of force against Gorbachev's government. The hard-liners did not plan, however, on significant public resistance. Boris Yeltsin, President of Russia-then the largest part of but still subordinate to the Soviet Union-rallied democratic forces in front of the Russian parliament building. An overwhelming surge of democratic sentiment eventually forced the plotters of the coup to stand down, and on August 22 the army withdrew its tanks from Moscow. On that same day, the leaders of the coup surrendered and were arrested. The Soviet military and intelligence forces had significant expe-

1 From this point forward, all references in this essay to "Bush" or "President Bush" refer to George H.W. Bush, the $41^{\text {st }}$ president who served from 1989-1993. His son, President George W. Bush, the $43^{\text {rd }}$ president who served from 2001-2009 is mentioned briefly in an earlier section but plays no further role in this essay. 
rience in asserting their authority, and the downfall of the coup in less than 100 hours was stunning.

Shortly after the failed coup, intense pressure began mounting on George Bush to give a speech in response to those events. The public pressure was to celebrate that the United States was, indeed, on the brink of winning a competition between great powers. President Bush, however, consistently declined to speak in public concerning the coup or his preferred outcomes for the USSR. While there were certainly scattered statements, these very much fit with Brummett's idea that silence is relative to what might be said. The Christian Science Monitor (Robinson, 1991, p. 1) argued that the administration "has moved too slowly to assist the reform movement and is now in danger of contributing to anarchy." The St. Petersburg Times (Editorial, p. A18) printed an editorial echoing that sentiment:

President Bush has had an oddly passive and cautious reaction to one of the most important and promising events of the $20^{\text {th }}$ century. The past 10 days may have shaken the rest of the world, but they haven't affected the president's [golfing] tee times.

If nothing else, one might have expected that a failed Communist coup and the subsequent collapse of the Soviet empire would be enough to provoke a more passionate and articulate response from the president of the United States. Doesn't the disintegration of an adversary whose nuclear threat has dominated U.S. foreign policy for almost 50 years warrant more emotion and imagination than Mr. Bush's words have offered so far?

The New York Times (Rosenthal, 1991) noted that, "The White House offered a strikingly low-key response to the event in the Soviet Union today," and that their "language seemed tepid at a time when the United States is seeing the aim of four decades of foreign policy, the crumbling of Communist power in the Soviet Union, come to pass." Newspaper editorial criticism from around the country was joined by pressure from leaders in Congress to say something more in response to the historic events in the Soviet Union. Then-Senator Robert Kerrey (D- MA, now former Secretary of State) had largely the same criticism when he said that Bush "didn't react in an intuitive fashion and say, 'this is not right." (Roberts, 1991, p. A2) Both of those speakers acknowledged that Bush made a statement denouncing the coup several days after it started, but they wanted the president to have said something immediately and more forcefully.

Bush faced sharp criticism from his domestic political opponents as well. In addition to the normal criticism of political opponents, this was due to the notion that great powers should be seen as being great. That would demand the sort of speaking and public positioning which precludes an intentional strategic silence. As the political climate in the Soviet Union quickly worsened, congressional leaders begin to criticize 
Bush. House Armed Services committee chairman Les Aspin (D- WI) demanded just days before Gorbachev's Christmas resignation that the Bush administration stop "dragging its heels in response to the collapse of the old Soviet Union." (Dewar, 1991, p. A36) Republican Senator Richard Lugar (IN) even criticized the president for failing to act quickly enough, and asked, "Is there the political will to move on it?" (Curtius, 1991, p. 30) These criticisms, both from the press and from American political leaders, reflected the very heavy pressure Bush faced to publicly celebrate the pending victory of the United States in the Cold War.

Intelligence reporting available in the GBPL, however, show that the public reaction in the U.S. did not grasp the work President Bush was doing out of sight of the cameras. Archival documents from the Bush presidency show that Bush acted as he did because he knew that the Soviet Union was going to break apart regardless of the words or actions of Western leaders. Intelligence reports also indicated, however, that the transition of power was not pre-destined to go smoothly. Indeed, the situation in Moscow was quite unstable, and some reactionary Communists were looking for a reason to launch another coup with potentially devastating consequences. Bush's challenge was to allow the transition to occur without the United States seeming to interfere, which would have given the Communist hardliners an excuse to rebel against outside influence.

Bush talked to President Yeltsin at 8:18 a.m. D.C. time on August 20,
1991 and got a dire report on the situation. Yeltsin said:

The situation is very complex. A group of eight individuals essentially put together an anti-constitutional coup. President Gorbachev is located in Farps in the Crimea. He is absolutely blocked, no way of reaching him...

The building of the Supreme Soviet and the office of the President is surrounded and I expect a storming of the building at any moment. We have been here 24 hours. We won't leave. I have appealed to 100,000 people standing outside to defend the legally elected government. (GBPL, August 20, 1991)

It would be the next day before Bush would be able to speak to Gorbachev in person. That call happened at 12:19 in the afternoon while the president was in Kennebunkport. Gorbachev indicated that he had been completely surrounded for 4 days and had all communication cut off, but said that his guards prevented him from being physically captured. Gorbachev stated that he had regained firm control of the government about an hour previously, and that, critically, he held the ministry of defense. Gorbachev also indicated that Yeltsin had been essential to defeating the coup. (GBPL, August 21, 1991). This gave Bush a problem: He knew that the immediate and gravest part of the coup was over, but there were now at least two real centers of power in the Soviet Union-both Gorbachev 
and Yeltsin. While Gorbachev said he would be grateful to Bush for publicly acknowledging the conversation, almost anything else Bush said would risk pushing a situation we did not yet fully understand to one side or another while the United States was still trying to identify its own interests.

In the weeks after the August coup, Bush continued to talk to both Yeltsin and Gorbachev. President Bush's primary concerns appeared to be internal stability in the USSR as well as control of the Soviet nuclear arsenalcertainly reasonable policy objectives for the United States. On September 25, Bush spoke with Yeltsin at 7:47 a.m. from the Oval Office. (GBPL, September 25,1991$)$ The themes of the conversation were building a personal relationship with Yeltsin and verifying that Yeltsin and Gorbachev were communicating internally. Bush started the call by noting that he read Yeltsin had been ill. He offered Yeltsin access to specialists in the United States. Yeltsin responded: "Mr. President, thank you. I am very grateful. Thank you for your personal attention to me. I don't know how to find the words to thank you... I am taking a rest of ten days. The doctors are looking me over and I am under observation. If things don't get better, perhaps I could take you up on your offer after consulting with my doctors." In other words, in private President Bush was clearly trying to build a link with the man he saw as a future ruler of Russia. Yeltsin also faced serious health challenges which complicated the political calculation. In addition, Yeltsin later added, "I want you to know that
Gorbachev and I are working decisively on reform and democratization and in a very friendly fashion. We call each other nearly every day. We are working very closely together." So long as Yeltsin and Gorbachev were willing to work together, there was very little to be gained from public intervention by the American president.

A conversation between Bush and Gorbachev two days later made plain that Bush was highly concerned with nuclear matters, and that he was closely coordinating his public statements with the Soviet leader. (GBPL, September 27, 1991). That conversation lasted 28 minutes, and in relevant part said:

The President: On dismantling nuclear warheads, where I propose we open discussions on the safe dismantling of nuclear warheads, on how we might enhance the safety and security of nuclear weapons, and how to improve nuclear command and control. I'd like to say you and I agree that this would be a good thing to do.

President Gorbachev: George, thank you for those clarifications. Since you're urging that we take steps, I can only give an answer in principle-since there is much that must be clarifiedand that answer is a positive one.

The President: I understand. How about if I say that I've consulted with Mikhail Gorbachev, and although he has had no time to study my initiative, that I am 
inclined to believe his response will be positive.

President Gorbachev: I think that will be very good.

After the incredibly tense moments of the coup, Bush was talking to both major leaders in Russia. He was being careful to avoid inflaming the situation and was likely hedging his bets about who would eventually become the more prominent leader. He was also working to advance the American policy priority of nuclear stability. Over the next month, however, President Bush came to believe that Yeltsin would succeed Gorbachev and that the Union would fail. Bush recorded in his diary on October 26, 1991, that he thought Gorbachev's time in office was to be short:

It is clear to me that things are an awful lot different regarding Gorbachev and the Center than they were. He's growing weaker all the time. I am anxious to see what his mood is. He's still important in nuclear matters, but all the economic stuff-it looks to me like the republics have been more and more exerting themselves. It will be interesting to figure out his mood. I remember not so long ago how he couldn't stand Yeltsin. How he, up at Camp David [in June 1990], made clear that he didn't think Yeltsin was going anywhere. But, now all that has changed. Reports recently that he might not be around long. The briefing book indicates this may be my last meeting with him of this nature. Time marches on. (Bush and Scowcroft, 1998, p. 548)

The meeting to which Bush referred in his diary occurred over lunch on October 29, 1991 in Madrid, Spain. The event was recorded in a Secret memorandum of conversation (GBPL, October 29, 1991), and the principals in attendance for the United States were George Bush, Secretary Baker, Chief of Staff John Sununu, National Security Adviser Brent Scowcroft, Press Secretary Marlin Fitzwater, U.S. Ambassador to the USSR Robert Strauss, NSC staffer Ed Hewett, State Department staffer Dennis Ross, and interpreter Peter Afanasenko. On the Russian side, President Gorbachev was joined by Minister of Foreign Affairs Boris Pankin, 5 other staffers (including the presidential spokesman), and an interpreter. Yeltsin was not present. Bush asked Gorbachev if the coup perpetrators had gone to trial, to which Gorbachev responded that it was "complicated." One of the plotters, Yanaev, had previously hosted President Bush in Kiev and was Gorbachev's "friend from university days." At that point in the conversation, Bush said, "It was stupid to try to overthrow you." Gorbachev then pointed out the very real threat of continuing upheaval by pointing to Scowcroft and saying, "This is what generals do sometimes." Stressing his desire to remain in office, Gorbachev then said, "All the superficial things you see are on the surfacedecisions, speeches, etc. They are not crucial things. Speeches are not what we need today. The issue is how we ac- 
tually make the transition to a market economy. It will be difficult. The social situation is very tense." This seems to underscore that President Gorbachev felt intense pressure, and speeches from Bush or anyone else would not be helpful in relieving that pressure.

Very real question were circling concerning the near-term future of the Soviet Union. A secret "National Intelligence Estimate" dated November 18, 1991 laid out four possible futures for the Soviet Union. (Fischer, 1999, p. 123) ${ }^{2}$ The only positive option was called "System Change." Under this scenario, there would be a relatively peaceful transition of power. While there would be economic turmoil, it would ultimately be manageable. Provided that the economic turmoil was properly managed, the Soviet Union would be replaced with several smaller states that were better disposed towards American interests.

The other three possibilities for the Soviet future were substantially worse. Under the "Chronic Crisis" scenario, there would be "political gridlock" and the "economy would verge on breakdown but somehow manage to limp along." (Fischer, p. 123) With the possibility of "Regression," hardliners would impose martial law and the downward economic spiral would accelerate. The worst possibility was "Fragmentation," under which there would be a "violent, chaotic collapse of system," "warfare within and between many republics," and widespread famine (Fischer, p. 123). The CIA was unsure of which of these scenarios would come to pass, but they summarized their findings this way: "In any event, we believe that the USSR in its present form will not exist five years from now." (Fischer, p. 126) While that estimate of the survival of the Soviet Union was overly generous, the CIA firmly believed that some sort of fundamental change would occur soon.

The question for Western policymakers was how to exert their influence to nudge the Soviet Union to the scenario of "System Change." This was tricky given that Gorbachev was slowing the movement to a new system for the USSR as he tried to remain in power. Even before the August coup Gorbachev tried to placate potentially reactionary hard-liners in the Soviet Communist Party leadership. A secret CIA document titled "The Soviet Cauldron," dated April 25, 1991, reported that:

In the midst of this chaos, Gorbachev has gone from ardent reformer to consolidator. A stream of intelligence reporting and his public declarations indicate that Gorbachev has chosen this course both because of his own political credo and because of pressures on him by other

2 Fischer's book was published by the CIA is comprised entirely of photocopies of documents the CIA has declassified. The authors of the original documents are unknown, because such information has been redacted by the CIA for security reasons. In this essay, I am attributing those documents to Fischer to help readers find the original documents. The citation is, of course, in the References section at the end of this essay. 
traditionalists, who would like him to use much tougher repressive measures. (Fischer, p. 112)

The further danger of Gorbachev's allowing traditionalist leaders to share power was expressed in the same CIA document: "Reactionary leaders, with or without Gorbachev, could judge that the last chance to act had come and move under the banner of law-and-order." (Fischer, p. 113) This prophecy was fulfilled only a few months later in the August coup. But the coup's failure did not render this concern moot. As the report indicated, Gorbachev was acting as he was in part "because of his own political credo,"that is, on his own commitment to maintaining the USSR as a Communist state. Additionally, the arrest of the coup leaders hardly removed all hard-liners from the Soviet government. Indeed, facing Boris Yeltsin's pressure to institute democratic reforms, the hard-liners represented a potential source of support for Gorbachev.

Bush did not speak appears to be due to the intelligence he was receiving and the conversations he held with Yeltsin and Gorbachev. As the CIA documents indicated, the hard-liners in the Soviet Union were particularly likely to strike out during this time. With reference to helping the Baltic republics break from the USSR, Bush later recalled that he did not want to "use the power and prestige of the United States, not to posture, not to be the first on board." (Bush and Scowcroft, p. 539) He feared that such public posturing, in the absence of advance discussions with the Soviets, could have disastrous consequences. As such, Bush followed a course of "calculated ambiguity." (Whalen, 1993, p. 86) The Soviets had sent tanks into Hungary in 1958 and Czechoslovakia in 1968 to secure the fraternal brotherhood of states seeking greater independence and liberalization, and it is not hard to imagine Moscow doing the same thing in response to a part of the USSR proper.

The reason for the calculated ambiguity was the hostility of Soviet hard-liners to the possible loss of their positions of privilege. As Joseph Whalen (1993, p. 4) put it:

Acute hostility on the conservative right [of the USSR] was based on the belief that victory of the reformers would not only lead to the destruction of the Soviet Union, but for more selfish reasons would deprive them of the heretofore privileged positions that they had enjoyed in the Soviet Union. In effect, this elite bears an historic similarity to the Tories of the American Revolution, the American supporters of the British King who had much to lose by victory of the colonial revolutionaries. Ideology was no longer a motivating force for the "Soviet Tories." Rather, as Elizabeth Teague, a specialist in Soviet Affairs at the RFE/RL Research Institute, concluded, the eight coup leaders represented the "naked interests" of the conservative ruling elite. 
While the leaders of the August coup acted for the naked interests of the ruling elite, there were also more subtle interests at play. Gorbachev faced tremendous pressure from men more conservative than he, and he was himself more conservative than were radical reformers such as Yeltsin. Publicly putting pressure on these actors by celebrating in the way demanded by the American press and much of the U.S. political establishment risked catastrophe. Writing almost four months before the attempted coup, the CIA observed: "Ominously, military, MVD, and KGB leaders are making preparations for a broad use of force in the political process." (Fischer, p. 114)

Another concern in the months between the August coup and December resignation was economic. A Council of Economic Advisers (CEA) memo written on August 19, 1991-the day of the coup-noted that the recentralization of economic and political control that would happen if those to the right of Gorbachev regained power would have a devastating impact on United States-Soviet relations in the areas of technical assistance, agriculture, energy, trade, special International Monetary Fund status, and Eastern Europe (GBPL, Box 99-0304-F). By August 26 , the CEA had concluded that it was critical to economic success that workers in the Soviet Union and investors from other nations have confidence that the hard-liners were truly removed from power (GBPL, Box 99-0304-F). However, it was even more important to the administration that the Soviet transition take place with all possible dispatch. In a memo dated September 3, 1991, the CEA argued that "clarifying the functions of the Union and Republic governments" (GBPL, Box 99-0304-F) was a key to economic success- something that certainly could not happen in an atmosphere filled with external pressure from the United States. Each of the CEA memos noted both great opportunities and profound risks for the Russian economy, and by September 23, 1991, the CEA had drawn up a memo outlining how the Soviet Union would be able to interact with the International Monetary Fund (GBPL, Box 99-0304-F).

The risks of destabilizing the situation in the Soviet Union were profound. The security risks included war among nuclear armed former Soviet republics. The political risks included a return to a hard-line repressive state. The risk of a downward economic spiral could only be alleviated by making sure that a peaceful transition of regime continued. There is a strong possibility that Bush's words might well have accelerated these risks. National Security Adviser Brent Scowcroft stated that even though he favored allowing the Soviet Union to break up, that position could not "be official US policy:"

Such a position would almost guarantee long-term hostility on the part of most Russians, who constituted the majority of the Soviet Union. We could actually do very little one way or the other to influence the outcome and, therefore, the downside of a public position favoring breakup 
seemed overwhelming. (Bush and Scowcroft, p. 543)

The position of the United States mattered immensely to the people and leaders of Russia and the other notquite-yet-former Soviet republics. Some in Russia were still sensitive as a result of an attempted American intervention against the rising Communist government in 1918 (Wright, 1991, p. A1). Gorbachev was particularly sensitive that Bush not say or do anything which would be perceived as supporting the independence of constituent Soviet republics-particularly the Ukraine. In a telephone call between Bush (speaking from Camp David) and Gorbachev on November 30, 1991, Bush made clear that if Ukraine formally voted for independence the United States and the West would have to find a way to acknowledge and support that. Gorbachev responded:

I won't hide that the leak from the White House saying that serious consideration was being given to recognizing the independence of Ukraine by the U.S.-especially because that leak came on the eve of the referendum - that this was taken negatively. It appears that the U.S. is trying not only to influence events, but to interfere...

We want very much that in this subtle and important question, there is no rush. I would like to recall the situation in Yugoslavia, which has led to the current state of affairs. But, George, the current situation is even more complicated than that of Yugoslavia. If someone in Ukraine says that they are seceding from the Union, and someone says they are supporting them, then it would mean that 12 million Russians and members of other peoples would become citizens of a foreign country. Crimea has already stated that if Ukraine distances itself from the Union, then Crimea will act to review the status of Crimea in Ukraine. The question of Donetsk will also emerge. (GBPL, November 30, 1991)

Gorbachev was hostile to even the perception that the United States might say something which dictated the path the dissolving Soviet Union should take. While the threats concerning Crimea and Ukraine and Donetsk were forestalled for two and a half decades, more recent events make it highly plausible to assume that the Russians might have been willing to use force to annex either of those territories. If Russia was actually willing to carry out those threats, then it becomes much easier to imagine that any number of other catastrophic outcomes might have occurred as Soviet leaders fought desperately to prevent the Union from crumbling. Critically, as Gorbachev said, the United States could not be seen to interfere.

Gorbachev's hold on power worsened over the next month, although he attempted to fight on until the very end. In a December 13, 1991 call between Gorbachev and Bush, the Soviet leader said that he continued to talk regularly to Yeltsin but that Yeltsin was increasingly asserting independence from 
him. (GBPL, December 13, 1991a) The Union was attempting to negotiate a new relationship amongst the constituent republics, and Secretary of State Jim Baker gave a speech indicating that the USSR was unravelling. To be clear, this would still be a strategic silence in the sense articulated by Brummett-the words of Secretary Baker certainly constituted a relative silence compared to a putative speech from President Bush, and an acknowledgment of facts on the ground-even if poorly worded-is a different thing from a call for a particular action to take place. That led to the following interaction between Gorbachev and Bush on the December 13 phone call:

President Gorbachev: George, I think Jim Baker's Princeton speech should not have been made, especially the point that the USSR had ceased to exist. We must all be more careful during these times. The main thing is to avoid confrontation.

The President: Let me be clear that I want to avoid confrontation. I don't want to interfere. I accept your criticism. I do not think Jim said it quite that wayhe said only "the USSR as we have known it" would be very different. That is a constructive suggestion that I will pass to him.

Gorbachev was extraordinarily sensitive to outside criticism on this December 13 call, and President Bush was deferential to him. It is hard to imagine a lot of circumstances where the American president would be will- ing to "accept your criticism" from the Soviet leader. That may have been an attempt to keep Gorbachev from lashing out and acting rashly. That was important, at least in part, due to a conversation Bush had earlier that day with Yeltsin. (GBPL, December 13, 1991b) Yeltsin told Bush that by the end of December or the start of January, the existing structures at the center of the Soviet Union would cease to exist. He also assured Bush that Soviet nuclear forces were accounted for and would be secured in the new commonwealth arrangement. He also said, "We are treating Mikhail Sergeyevich Gorbachev with the greatest respect and warmly. It is up to him to decide his own fate." Yeltsin repeated similar words later in the same call. It is hard to interpret that last line as anything other than an implicit threat that Gorbachev might fare either well or poorly in the new regime based on his own choices.

In short, during the months from August through December 1991 there was almost nothing that George Bush could say that would make the situation in the USSR better. There were, however, a good number of things he might have said to make the situation worse. If the situation became worse, the consequences were potentially devastating. The Christmas Day call between Gorbachev and Bush (GBPL, December 25, 1991) made clear that Bush and Gorbachev had a warm personal affection for one another, and it is stunning to read President Gorbachev say that his country will cease to exist in 2 hours as he discusses a calm and orderly plan for the handover of the Soviet nuclear 
arsenal to Russia. Given all this, and acknowledging the difficulty in arguing the counter-factual case, Bush's silence prior to Gorbachev's resignation seems the best strategic choice available. Hurst (1999) provided insight when he argued that:

Most crucially of all, when the Soviet Union finally collapsed, it did so peacefully. While the Bush administration cannot claim all of the credit for this fact, it did play a significant role. Above all, as with the collapse of communism in eastern Europe, the Bush administration deserves credit as much for what it did not do as for what it did. Bush did not gloat, he was not triumphalist, he did not seek to overtly or crudely exploit the Soviet Union's misfortunes or intervene in internal Soviet affairs. As with eastern Europe, Bush's concern to 'do no harm' served the United States and the rest of the world well. (p. 167)

The situation changed quickly, of course, after Yeltsin assumed power on December 25, 1991. While President Bush made occasional statements concerning Russia and the other former Soviet republics in 1992, those statements continued to be limited and fairly restrained in nature. The United States then had an opportunity to influence a state which very much wanted to view itself as a great power but was cognizant of its own limitations. The newly independent republics also badly needed international financial assistance, and that made them unlikely to retaliate against rhetorical pressure from the U.S. and allied nations. My point in this essay isn't that presidents should stay quiet and let events run their course-very much to the contrary, I believe American policy goals in the post-Soviet states would have benefitted from the public intervention of President Bush in 1992. My argument is, instead, that great powers needn't always publicly position themselves as being great. They should seek to advance their policy goals, and sometimes that is better done through a strategic silence. Between the August 1991 Soviet coup and the December 1991 dissolution of the USSR, Bush made the best available choice in practicing an intentional strategic silence. So what does this specific case-and the limited additional work in intentional strategic silence-tell us about contests between great powers?

\section{Conclusion}

The broad theme which emerges is this-when the rhetorical inter1 vention of a great power would help advance their policy goals, they should by all means do it. For example, in 1992 an economically disintegrating formerly Soviet block badly needed financial help. President Bush might have been able to rally support for a larger aid package which could, theoretically, have stabilized the economic transition without allowing a few well-connected private individuals to control state resources. Similarly, while President Bush did very well to not challenge the Chinese in the immediate aftermath of the Tiananmen Square massacre, at some 
later point in 1989 or 1990 there was the opportunity to advance American interests in China. Sometimes a speech from the leader of a great power does indeed serve to advance a policy goal. The critical thing, though, is advancing the relevant interest rather than puffing up one's chest.

What President Bush was being called to do in the Fall of 1991 was, in essence, puffing up his chest. Of course Americans wished to celebrate our apparent victory at the end of four or five decades of cold war, and George Bush absolutely wanted to position himself as well as possible for his re-election bid the following year. That, however, would have been contrary to the advancement of interests which makes a great power great. Speaking in August 1991 might, for example, have given support to one side or another in Moscow when the American interest was that the military not start shooting (at anyone) and that the nuclear weapons be accounted for. Speaking between roughly Labor Day and Christmas Day might have done the same thing, or it might have caused one side to lash out in a desperate attempt to exert influence or gain position. Those who are on the point of losing positions of privilege in a declining superpower are going to have some reaction to the statement of an external enemy.

This is consistent with the other available cases. The studies on Lincoln and the study on President John- son generally reached the conclusion that one is best served by remaining silent when their words lack the power to bring about the desired change. While I am not privy to Saudi reasons for maintaining a strategic silence in their blockade of Qatar, it is very likely that is what they did-recognizing that sometimes interests are better advanced through silence. The documents on the fall of the Berlin Wall in 1989 are exceptionally clear that a speech by Bush would have provoked an unfavorable response from the Soviet Union, and in the following months would have risked angering partners in the western alliance. Great powers should certainly speak when it advances their interests, but they are generally better served remaining silent when they lack the power to change things or when those words would provoke a reaction. That silence might be relative or absolute, but is certainly different from trumpeting one's successes. In moments of routine international business, states quite frequently have the opportunity to use public diplomacy or other measures to be seen as great powers. In moments of crisis, however, states should seriously question whether having a prominent leader make a forceful public statement actually serves the desired purpose. Great leaders and great powers become such by advancing the interests of their state rather than by seeking to be seen as great. It would have been good to publicly celebrate winning the Cold War, but it was better to actually win it. 
William F Harlow, Ph.D., is Professor and Chair of the Department of Communication at The University of Texas Permian Basin (UTPB). He earned a Ph.D. in Speech Communication from Texas A\&M in 2002, and later that year he started his professional career at Texas Tech. In 2003, he became a Foreign Service Officer and served with the State Department in Mexico City and Abuja, Nigeria. In 2007 he left the Foreign Service to serve as Secretary of the International Boundary and Water Commission (U.S.- Mexico). He also taught graduate-level intelligence analysis courses at American Public University from 2007-2010. In 2008, Dr. Harlow began a full time faculty career at UTPB, where he served as Dean of Undergraduate Success from 2012-2019. When he is not teaching or spending time with his wife and kids, Dr. Harlow coaches Little League baseball. He would be delighted to pursue joint work on future scholarly projects. The best way to reach him is via email to harlow_w@utpb.edu.

\section{References}

Black, E. (1994). Gettysburg and silence. Quarterly Journal of Speech, 80, 21-36.

Bostdorff, D.M. (1994). The presidency and the rhetoric of foreign policy crisis. University of South Carolina Press.

Brummett, B. (1980). Towards a theory of silence as a political strategy. Quarterly Journal of Speech, 66, 289-303.

Bush, G., and Scowcroft, B. (1998). A world transformed. New York: Alfred A. Knopf.

Curtius, M. (1991, December 19). Lugar raps U.S. response to Soviets. Boston Globe, sec. National/Foreign, p. 30.

Dewar, H. (1991, December 20). Bush reaction to Soviets criticized; Aspin, other on Hill urge more aggressive, coordinated effort. Washington Post, sec. A, p. 36.

Dugard, J. (1982). Silence is not golden. Foreign Policy, 46, 37-48.

Editorial, (1991, August 29). He'd rather be golfing. St. Petersburg Times, sec. A, p. 18.

Fischer, B.B. (1999). At Cold War's end: U.S. intelligence on the Soviet Union and Eastern Europe, 1989-1991. Washington, DC: Central Intelligence Agency. 
George Bush Presidential Library, College Station, Texas (hereafter: GBPL). Memorandum of Telephone Conversation, August 20, 1991. Available at https://bush 41library.tamu.edu/files/memcons-telcons/1991-08-19--Yeltsin.pdf as of July 25, 2021. This document was originally classified as Secret.

GBPL. Memorandum of Telephone Conversation, August 21, 1991. Available at https://bush41library.tamu.edu/files/memcons-telcons/1991-08-21--Gorbachev. pdf as of July 25, 2021. This document was originally classified as Secret.

GBPL. Memorandum of Telephone Conversation, September 25, 1991. Available at https://bush41library.tamu.edu/files/memcons-telcons/1991-09-25--Yeltsin.pdf as of July 25,2021 . This document was originally classified as Secret.

GBPL. Memorandum of Telephone Conversation, September 27, 1991. Available at https://bush41library.tamu.edu/files/memcons-telcons/1991-09-27--Gor bachev.pdf as of July 25,2021 . This document was originally classified as Secret.

GBPL. Memorandum of Conversation, October 29, 1991. Available at https:// bush41library.tamu.edu/files/memcons-telcons/1991-10-29--Gorbachev\%20[1]. pdf as of July 25, 2021. This document was originally classified as Secret.

GBPL. File Series: 1999 Freedom of Information Act (FOIA) requests. Box: 990304-F Dissolution of the Soviet Union Box 1/7. File: Paul Wonnacott Files Vol. I [2 of 2]. Document: Council of Economic Advisers Memorandum dated August $19,1991$.

GBPL. File Series: 1999 FOIA requests. Box: 99-0304-F Dissolution of the Soviet Union Box 1/7. File: Paul Wonnacott Files Vol. I [2 of 2]. Document: Council of Economic Advisers Memorandum dated August 26, 1991.

GBPL. File Series: 1999 FOIA requests. Box: 99-0304-F Dissolution of the Soviet Union Box 1/7. File: Paul Wonnacott Files Vol. I [2 of 2]. Document: Council of Economic Advisers Memorandum dated September 3, 1991.

GBPL. File Series: 1999 FOIA requests. Box: 99-0304-F Dissolution of the Soviet Union Box 1/7. File: Paul Wonnacott Files Vol. I [2 of 2. Document: Council of Economic Advisers memorandum dated September 23, 1991.

GBPL. File Series: 1999 FOIA requests. Box: 99-0304-F Dissolution of the Soviet Union Box 1/7. File: Paul Wonnacott Files Vol. I [2 of 2]. Document: Council of Economic Advisers Memorandum dated January 8, 1992.

GBPL. Memorandum of Telephone Conversation, November 30, 1991. Available at 
https://bush41library.tamu.edu/files/memcons-telcons/1991-11-30--Gorbachev. pdf as of July 25, 2021.

GBPL. Memorandum of Telephone Conversation, December 13, 1991a. Available at https://bush41library.tamu.edu/files/memcons-telcons/1991-12-13--Gorbachev.pdf as of July 25, 2021.

GBPL. Memorandum of Telephone Conversation, December 13, 1991b. Available at https://bush41library.tamu.edu/files/memcons-telcons/1991-12-13--Yeltsin.pdf as of July 25, 2021.

GBPL. Memorandum of Telephone Conversation, December 25, 1991. Available at https://bush41library.tamu.edu/files/memcons-telcons/1991-12-25--Gorbachev. pdf as of July 25, 2021.

Gunderson, R.G. (1961). Lincoln and the policy of eloquent silence: November, 1860, to March, 1861. Quarterly Journal of Speech, 47, 1-9.

Harlow, W.F. (2006). And the wall came tumbling down: Bush's rhetoric of silence during German reunification. In M.J. Medhurst (Ed.), The rhetorical presidency of George H.W. Bush (pp. 37-55). Texas A\&M University Press.

Harlow, W.F. (2010). Silence as presidential argument in international affairs. Texas Speech Communication Journal, 35, 76-95.

Harlow, W.F. (2011a). The triumph of silence: President George H.W. Bush's refusal to denounce apartheid in South Africa. Rhetoric and Public Affairs, 14, 45-68.

Harlow, W.F. (2011b). Silence as the U.S. strategic response to Nigeria's elections. Relevant Rhetoric, 2, 1-14.

Harlow, W.F. (2014). The rhetoric of silence and the collapse of the Soviet empire. American Communication Journal, 16, 52-66.

Harlow, W.F. (2018a). Strategic silence. In R.L. Heath \& W. Johansen (Eds.), International encyclopedia of strategic communication. John Wiley \& Sons.

Harlow, W.F. (2018b). Strategic silence as a frame for understanding the $2017 \mathrm{em}$ bargo against Qatar. Journal of Contemporary Rhetoric, 7, 217-226.

Harlow, W.F. (2020). Strategic silence in President George H.W. Bush's response to Tiananmen Square. American Journal of Humanities and Social Sciences, 6, 1-16. 
Hurst, S. (1999). The foreign policy of the Bush administration: In search of a New World Order. London: Cassell.

Johannesen, R.L. (1974). The functions of silence: A plea for communication research. Western Speech, 38, 25-35.

Kiewe, A. (1994). The modern presidency and crisis rhetoric. Praeger.

Medhurst, M.J. (1988). Truman's rhetorical reticence, 1945-1947: An interpretive essay. Quarterly Journal of Speech, 74, 52-70.

Ritter, K. (1994). Lyndon B. Johnson's crisis rhetoric after the assassination of John F. Kennedy: Securing legitimacy and leadership. In A. Kiewe (Ed.), The modern presidency and crisis rhetoric (pp. 73-89). Praeger.

Roberts, J. (1991, September 5). Kerrey knocks Bush's action during coup. San Francisco Chronicle, sec. A, p. 2.

Robinson, W.V. (1991, August 26). Bush is "Biding Time;" Administration stands pat; Analysts warn against inaction. Christian Science Monitor, sec. National/Foreign, p. 1.

Rosenthal, A. (1991, August 25). Bush low key on Soviet moves and aid pressure. New York Times, front page.

Whalen, J.G. (1993). CRS report for Congress: Gorbachev's decline and fall: From failed coup to collapse of empire, August- December 1991. In J.G. Whalen (Ed.), Soviet diplomacy and negotiating behavior, Volume IV (p. 4-90). Buffalo, NY: William S Hein \& Co.

Wright, R. (1991, September 2). Caution is watchword as U.S. faces a new era; Policy: Planners want to avoid moves such as the ill-advised intervention in the Soviet Union in 1918. Los Angeles Times, sec. A, p. 1. 